\title{
Endophytes in changing environments - do we need new concepts in forest management?
}

\author{
Doris Krabel $^{(1)}$, Kristin Morgenstern ${ }^{(1)}$, Sven Herzog ${ }^{(2)}$
}

The occurrence of endophytic fungi, hosted by living tissues of forest trees seems to be a common phenomenon. Numerous studies show that these colonists are mostly symptomless or even live in a symbiotic relationship to the host plant. Our investigations on Douglas-fir and Rhabdocline needlecast show that Rhabdocline pseudotsugae (Sydow), which has been described exclusively as an obligatory needle pathogen up to now, is able to persist symptomless in different types of plant tissues and therefore an endophytic lifestyle has to be assumed. Whether this lifestyle is part of the infection strategy of the fungus is still unclear. However, examples of other wood associated fungi lead us to the hypothesis that environmental such as climate conditions are able to trigger the phenomenon of changing from a mutualist to a virulent parasite.

Keywords: Douglas-fir, Endophytes, Rhabdocline Needlecast, Climate Change

\section{Introduction}

It has been well described by Stone (1987), Carroll \& Carroll (1978), McCutcheon et al. (1993) and Sieber (2007) that for Douglasfir Rhabdocline parkeri (order Heliotiales Kirk et al. 2001) is the dominant needle endophyte with strict host specificity. This fungus infects single epidermal cells, which die due to the infection. The microorganism persists in the needle as a multicellular thallus without any further growth. In contrast to Rhabdocline parkeri, the closely related species Rhabdocline pseudotsugae, Rhabdocline oblonga, Rhabdocline obovata, Rhabdocline epiphylla and Rhabdocline weirii are fungi which induce Rhabdocline needlecast, one of the most economically important diseases of Douglas-fir (Catal et al. 2010), because it can cause substantial losses in Christmas tree plantations (Chastagner 2001). In 1930 the pathogen of Rhabdocline needlecast was first described for Germany by v. Geyr (1930). A detailed description of disease symptoms and life cycle can be found at Van Vloten (1932), Stephan (1981) and Butin (1996). Rhabdocline pseudotsugae which is classified into the class of Ascomy cota is a highly specialized parasite whose one-year life cycle is closely linked to the seasonal growth cycle of Douglas-fir needles (Van Vloten 1932). Small yellow-green spots are the first indication of the disease. They occur in autumn on this year's needles. During winter, the spots become necrotic and brown. The characteristic orange-yellow to rust-colored fruiting bodies mature in May/June on the needle surface. High air humidity promotes the process of ascospore release and infection of the young sprouting needles. Finally the needles become brown and die (Stephan 1981, Butin 1996). A repeated infection causes a significant decrease in growth or even the death of the infected trees (Stephan 1981). Up to now it seems to be clear that ascospores infect the sprouting needles and afterward they directly penetrate through the needle epidermis into the host cells (Van Vloten 1932, Lyr 1958, Stephan 1980, 1981, Butin 1996). The current state of knowledge on the morphology and lifecycle of the fungus is mainly based on macroscopic and microscopic investigations of characteristic fungal fruiting bodies, spores and needles showing symptoms of infection. The present study is the first investigation which verifies Rhabdocline pseudotsugae in different type of plant material other than needles. There are no previous investigations which show that the fungus shows an endophytic lifestyle. Our report is focused on the transmittance of the pathogen beside the regular distribution via ascospores, placed in the context of the idea that Rhabdocline pseudotsugae behaves in part as a latent pathogen and that this way of life can become

Tab. 1 - Screening of different type of plant material (varieties and tissue).

\begin{tabular}{|c|c|c|}
\hline $\begin{array}{l}\text { Material } \\
\text { (number of genotypes } \\
\text { x sampling location) }\end{array}$ & Variety & $\begin{array}{l}\text { Number of samples infected } \\
\text { with Rhabdocline pseudotsugae }\end{array}$ \\
\hline $\begin{array}{l}3 \times \text { needles, cambium, } \\
\text { buds }\end{array}$ & viridis $x$ glauca & $\begin{array}{l}1 \times \text { needles, cambium positive; buds negative } \\
1 \times \text { needles and cambium positive, buds negative } \\
1 \times \text { needles, cambium, buds positive }\end{array}$ \\
\hline $11 \mathrm{x}$ needles & viridis & $11 \mathrm{x}$ negative \\
\hline $4 \mathrm{x}$ needles & glauca & $4 \mathrm{x}$ negative \\
\hline $8 \mathrm{x}$ embryo & glauca $x$ viridis & $3 \times$ positive, $5 \times$ negative \\
\hline $15 \mathrm{x}$ embryo & viridis $x$ glauca & $5 \times$ positive, $10 \times$ negative \\
\hline
\end{tabular}

$\square$ (1) Molecular Physiology of Woody Plants Group, Dresden University of Technology, Pienner Str. 7, D-01737 Tharandt (Germany); (2) Institute of Silviculture and Forest Protection, Dresden University of Technology, Pienner Str. 8, D-01737 Tharandt (Germany)

@ Doris Krabel (krabel@forst.tudresden.de)

Received: Dec 17, 2012 - Accepted: Feb 05, 2013

Citation: Krabel D, Morgenstern K, Herzog $S, 2013$. Endophytes in changing environments - do we need new concepts in forest management? iForest 6: 109-112 [online 2013-03-05] URL: http://www.sisef.it/ iforest/contents/?id=ifor0932-006

Communicated by: Marco Borghetti

problematic under certain host-related stress conditions.

\section{Material and methods}

Material and methods are following Morgenstern \& Krabel (2013). In short: buds, needles, cambial meristem as well as embryos were sampled from a 20 -year-old controlled cross-breeding population. Around $94 \%$ of the trees showed clear symptoms of infection by some type of pathogenic needle cast. Additionally apparently healthy looking trees from the Forest Botanical Garden Tharandt were used as a negative control (noninfected). Needles with fruiting bodies of Rhabdocline pseudotsugae were collected in May 2011 serving as positive control. Embryos were dissected from seeds which originated from a controlled cross-breeding of interior and coastal varieties of Douglas-fir.

Genomic DNA was isolated from all types of plant tissues described above. For isolation of genomic plant DNA an extraction protocol, modified after Doyle \& Doyle (1987) was used (Morgenstern \& Krabel 2013). For extraction of fungal DNA the DNeasy Plant Mini Kit (Qiagen $\mathrm{GmbH}$, Hilden, Germany) was used. Based on studies by Catal (2002), a nested PCR protocol was established for the detection of Rhabdo- 
cline pseudotsugae. Primers ITS1F, ITS4, RPP1 and RPP4 were used according to Catal (2002). PCR conditions are described in detail by Morgenstern \& Krabel (2013).

For the examination of embryos the Phire Plant Direct PCR Kit (Finnzymes, Part of Thermo Fisher Scientific, Espoo, Finland) was used. PCR was carried out with primer pair ITS1F/ITS4 according to the instructions of the manufacturer in a total volume of $20 \mu 1$.

Fragment analysis of PCR products was carried out with the ALFexpress II sequencer (Amersham Pharmacia Biotech Europe $\mathrm{GmbH}$, Freiburg, Germany) in a polyacrylamide gel (ReproGel High Resolution, GE Healthcare Europe GmbH, Munich, Germany).

\section{Results and discussion}

General aspects of an endophytic lifestyle

Hawksworth et al. (1995) suggested that before using the term endophyte one should clearly define it. We will follow the definition of Saikkonen et al. $(1998,2004)$ which defines endophythes as microorganisms which live the entire or at least parts of their life cycle asymptomatically inside plant tissues or inside plant cells. This includes latent pathogens as well as endophytic living bacterias (Wilson 1995) and endophytic fungi. Endophytic fungi have been found in all woody plants which have been investigated for endophytes (Saikkonen et al. 1998) A comprehensive overview of the actual knowledge about this subject related to forest trees is given by A. M. Pirttilä and A. C. Frank in the book "Endophytes of forest trees" which has been published in 2011 . Other excellent reviews focusing on endophytic fungi in woody plants are those e.g. from Carroll (1986, 1988), Petrini (1991),
Schulz \& Boyle (2005), Stone \& Petrini (1997) and Stone et al. (2004).

Although the endophyte-plant interactions are products of evolutionary development (Sieber 2007), the lifestyle (mutualism, commensalism, parasitism) of a microorganism, which is living inside a plant is not always obvious and the question may rise for what is such a relationship good for? A more or less mutualistic relationship occurs in the case the endophyte provides the host plant with some ecological advantages. On the other hand, some apathogenic endophytes may become virulent (Brown et al. 1998, Misaghi \& Dondelinger 1990) under certain environmental conditions or by mutation (Freeman \& Rodrigez 1994). In general, it is suspected that the endophyte-plant interaction is as prevalent as the mycorrhiza-plant interaction, with advantages for both partners (Carroll 1988, Sieber 2007). By the production of specific metabolites and biologically active chemicals which strengthen the plant, it reduces the level of herbivore damage, e.g., gall insects. A successful interaction can also be characterized by an increased resistance of the host against pathogens by "controlling" these pathogens (e.g., white pine blister rust in Pinus monticola - Ganley et al. 2008). For the microorganisms the advantage may be the persistence in a host over a longer period and the dispersal with the next host generation up to the moment the host's living conditions change (Saikkonen et al. 1998). Such changes of environmental conditions mostly go in parallel with changes of the milieu inside the plant tissue (when the plant is stressed, e.g., caused by wounding or decreased vitality of the host plant) and causes an adaptation reaction of the endophytic microorganism (Saikkonen et al. 1998). Examples are xylem fungi such as Fomes fomentarius (Brasier \& Strouts 1976) and Nectria coccinea (Sieber 2007), which are known to adopt a non-pathogenic behavior under limited oxygen ratio and/or nutrient, while they may switch to parasitism when the above conditions change (e.g., by wounding - Oses et al. 2008). In this case the host is latent infected by "non-active pathogens" until internal cell conditions change and the endophyte becomes virulent. The latent infection hypothesis is proposed by Boddy \& Rayner (1983). This hypothesis is closely connected to the assumption that a certain density of tissue colonization is required for changing into a pathogenic behavior. Sieber (2007) reports that as soon as colonization density of the endophyte reaches a certain threshold the plant organ (e.g., needles) may die. This threshold can be reached very soon in case the living conditions of the host become unfavorable, e.g., by a lack of light in dense stands.

As stated by Sieber (2007), depending on the selection pressure, it may also be the case that a pathogenic endophyte may change into non-pathogenic and back again.

\section{Hints for an endophytic lifestyle of}

Rhabdocline pseudotsugae and its consequences

Our investigations on Rhabdocline needlecast clearly confirm that the Ascomycete Rhabdocline pseudotsugae known as a pathogen can be identified inside infected Douglas-fir needle material as well as in different types of plant tissues like buds, cambium and embryos (Fig. 1). This result is surprising insofar as the fungus has been classified exclusively as a needle parasite up to now. As already Petrini et al. (1992) stated that far too little is known about endophytes of woody plants to assume that they are all non-systemic, our findings are not suited to explain whether the fungal material is distributed systemically via needles to cambial tissue, buds and seeds' embryos, or whether these

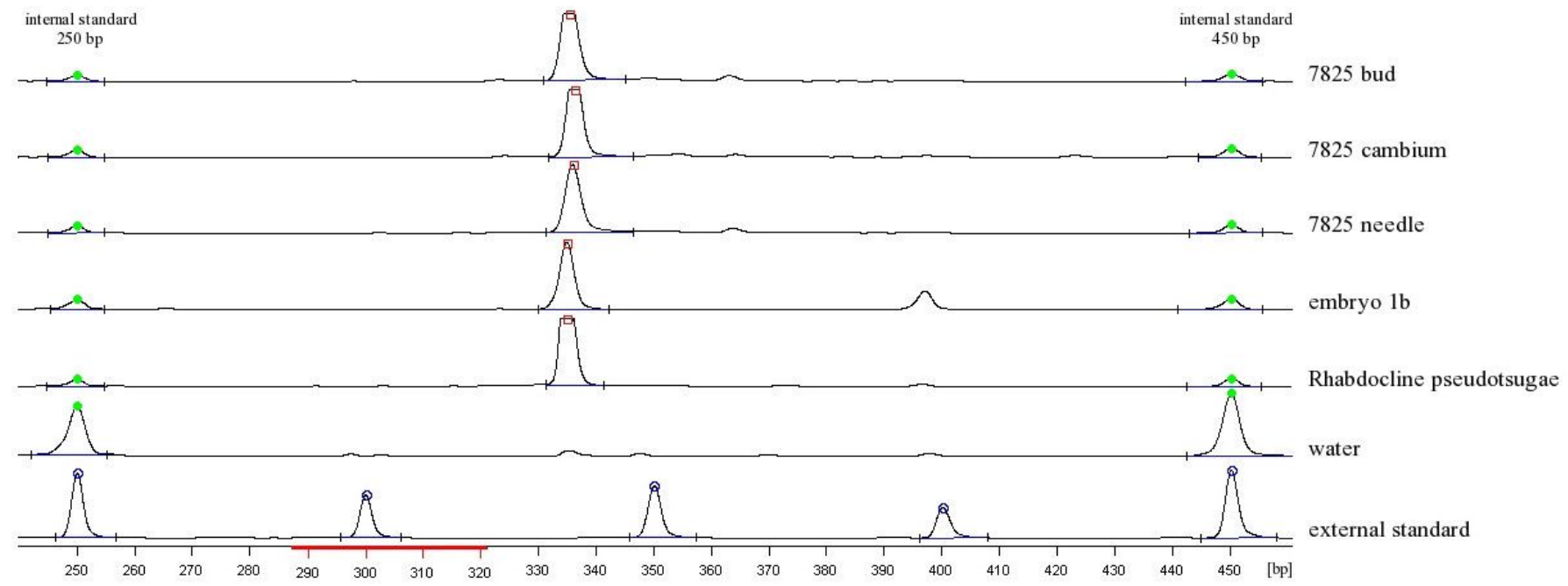

Fig. 1 - Fragment analysis at the ALFexpress II sequencer. Polyacrylamide gel shows Rhabdocline pseudotsugae specific bands (335bp) in infected plant tissues as well as in the positive control (fruiting body of Rhabdocline pseudotsugae). The negative control is a water sample. 
tissues are locally infected but do not show any symptoms of infection. To our opinion a systemic transmittance seems to be more probable than a non-systemic one, because infection and symptoms of a disease of other tissues than needle material by Rhabdocline pseudotsugae has never been described before.

Nevertheless a vertically and maternally distribution of fungal material via seeds can imply an additional source of infection beside the ascospores which seems to infect only needles. Latent infections of plant material by pathogens have been recognized for a long time (Gäumann 1951) and they may become virulent under environmental stress (Brown et al. 1998). For Douglas-fir such stress situations are realized in dense stands with reduced air circulation and high humidity. This is the case even in young stands around 10 years of age or in older stands when crown contact starts to be intense. But the question remains open whether the fungus is really able to persist symptomless in a young plant for more than one decade. The ecological significance of such a strategy is obvious. The persistence in Douglasfir seeds and later on in the young plant helps the pathogen to be transmitted over larger distances and to colonize new areas independently from its sexual reproduction.

\section{Host specificity of Rhabdocline pseudotsugae}

It has been described that Rhabdocline pseudotsugae prefers to infect Douglas-firs belonging to the intermountain (glauca or "blue") variety and that genotypes belonging to the coastal (viridis or "green") variety are less susceptible (Chastagner 2001). But Chastagner (2001) also reports on the one hand about observations that Rhabdocline needlecast can cause extensive damage to susceptible genotypes of the viridis variety, and on the other hand that there is considerable genetic variation in susceptibility to the disease of glauca provenances. Our results show that, among a total of 120 seeds from 6 German viridis provenances, 10 to $42 \%$ genotypes per provenance show infection.

Based on the above results and those reported in Tab. 1, the equivalences viridis $=$ resistant and glauca $=$ susceptible have to be reconsidered.

Previous studies reported that natural grass populations are usually a mosaic of uninfected and infected plants (Saikkonen et al. 1998), which implies that the host genotype is the crucial factor for susceptibility to the pathogen. This might be also true for Rhabdocline pseudotsugae and has to be tested in further investigations.

\section{Conclusions}

Up to now most approaches for pathogen characterization were based on visual detec-

\section{Situation}

Rhabdocline pseudotsugae is a latent pathogen colonizing the entire host plant independently fromits variety

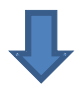

\section{Questions}

Which factors may affect the interaction between host and

endophyte:

- environmental factors?

- a new, more aggressive strain of the fungus?

- is a specific threshold of tissue colonization required for the outbreak of the disease?

- which role does the genotype of the host plant play?

- which role does the vitality of the host plant play?

- how do climatic changes influence the interaction?

- how other endophytic organisms do influence the interaction hostendophyte?

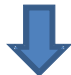

Possible measures for avoidance/reduction of infection
- control of seed material before distribution
- control of plant material before distribution
- avoid high plant density within stands
- preference of mixed stands

tion in tissues of its typical structures (e.g., ascospores) using a microscope. Molecular methods based on the detection of fungi DNA in host tissues are a very sensitive technique available since a few years.

Our findings raise the question whether previous studies failed to detect the fungus in other plant tissues (independently from the host variety) due to a lack of methodological sensitivity, or whether our findings are due to a type of the fungus' endophytic lifestyle, and therefore a plant-parasite interaction different from what is reported in previous investigations. In the latter case, we have to ask whether Rhabdocline pseudotsugae is only one example of a larger group of organisms causing "novel diseases" and emerging due to climatic changes. The role of environmental factors (like mild winter temperatures, drought periods alternating with high precipitation during the vegetation period etc.) has not been investigated up to now in this context. Several authors have tried to explain the infection pathway and history of the so called "novel" serious diseases, like ash dieback (Kowalski 2006), bleeding cancer in Horse chestnut (Aesculus hippocastanum - Green et al. 2010) or Cryptostroma corticale the sooty bark disease of sycamore (Acer pseudoplatanus Bevercombe \& Rayner 1984). They hypothesized that climatic changes might induce stress reactions in the host plants which may favor the spread of aggressive pathogens. On the other hand, Chalara fraxinea, the fungus which seems to be responsible for the ash dieback, is known as a saprophyte and not as an aggressive parasite. Although the disease is spreading very fast all over Europe, the infection path is still unclear (Wulf \& Schumacher 2005).

Nevertheless, the results reported in this study raise new concerns on the possible consequences of such a type of plant infection, and provide some suggestions to avoid infection of Douglas-fir tissues with Rhabdocline pseudotsugae (see Fig. 2).

\section{References}

Bevercombe GP, Rayner ADM (1984). Population structure of Cryptostroma corticale, the causal fungus of sooty bark disease of sycamore. Plant Pathology 33: 211-217. - doi: 10.1111/j.13653059.1984.tb02642.x

Boddy L, Rayner ADM (1983). Origins of decay in living deciduous trees: the role of moisture content and a re-appraisal of the expanded concept of tree decay. New Phytologist 94: 623641. - doi: 10.1111/j.1469-8137.1983.tb04871.x Brasier CM, Strouts RG (1976). New records of Phytophthora on trees in Britain. In: "Phytophthora root rot and bleeding canker of Horse chestnut (Aesculus hippocastanum L.)". European Journal of Forest Pathology 6: 129-136. doi: 10.1111/j.1439-0329.1976.tb00517.x Brown KB, Hyde KD, Guest DI (1998). Preliminary studies on endophytic fungal communities of Musa acuminata species complex in Hong Kong and Australia. Fungal Diversity 1: 27-51. Butin H (1996). Krankheiten der Wald- und Park- 
bäume. Georg Thieme Verlag, Stuttgart, Germany.

Carroll GC (1986). The biology of endophytism in plants with particular reference to woody perennials. In: "Microbiology of the Phyllosphere" (Fokkema NJ, Dem Heuvel J eds). Cambridge University Press, Cambridge, UK, pp. 205-222.

Carroll GC (1988). Fungal endophytes in stems and leaves: from latent pathogen to mutualistic symbiont. Ecology 69: 2-9. - doi: 10.2307/ 1943154

Carroll GC, Carroll FE (1978). Studies on the incidence of coniferous needle endophytes in the Pacific Northwest. Canadian Journal of Botany 56: 3034-3043. - doi: 10.1139/b78-367

Catal M (2002). Development and testing of oligonucleotide probes for detection and identification of some fungal pathogens and endophytes of conifers. PhD thesis, Department of Plant Pathology, Michigan State University, East Lansing, MI, USA, pp. 399.

Catal M, Adams GC, Fulbright DW (2010). Evaluation of resistance to Rhabdocline needlecast in Douglas fir variety shuswap, with quantitative polymerase chain reaction. Phytopathology 100 (4): 337-344. - doi: 10.1094/PHYTO-100-4 0337

Chastagner GA (2001). Susceptibility of intermountain Douglas-fir to Rhabdocline needle cast when grown in the Pacific Northwest. Plant Health Progress. - doi: 10.1094/PHP-2001-1029. 01-RS

Doyle JJ, Doyle JL (1987). A rapid DNA isolation procedure for small quantities of fresh leaf tissue. Phytochemistry Bulletin 19: 11-15.

Freeman S, Rodrigez PJ (1994). Genetic conversion of a fungal plant pathogen to a non-pathogenic, endophytic mutualist. Science 260: 75-78. - doi: 10.1126/science.260.5104.75

Gäumann E (1951). Pflanzliche Infektionslehre (2 edn). Birkhäuser, Basel, Switzerland, pp. 681.

Ganley RJ, Sniezko RA, Newcombe G (2008). Endophyte-mediated resistance against white pine blister rust in Pinus monticola. Forest Ecology and Management 255: 2751-2760. - doi: 10.1016/j.foreco.2008.01.052

Geyr H (1930). Die Douglasienschütte in Deutschland. Der deutsche Forstwirt 12: 371 .
Green S, Studholme DJ, Laue BE, Dorati F, Lovell $\mathrm{H}$, Arnold D, Cottrell JE, Bridgett S, Blaxter M, Huitema E, Thwaites R, Sharp PM, Jackson RW, Kamoun S (2010). Comparative genome analysis provides insights into the evolution and adaptation of Pseudomonas syringae pv. aesculi on Aesculus hippocastanum. PLoS ONE 5 (4): e10224. - doi: 10.1371/journal.pone.0010224

Hawksworth DL, Kirk PM, Sutton BC, Pegler DN (1995). Ainsworth and Bisby's dictionary of Fungi. Cambridge University Press, CAB International, UK.

Kirk PM, Cannon PF, David JC, Stapler JA (2001). Ainsworth and Bisby's dictionary of the Fungi. CAB International, Oxon, UK.

Kowalski T (2006). Chalara fraxinea sp. Nov. associated with dieback of ash (Fraxinus excelsior) in Poland. Forest Pathology 36: 264-270. doi: $10.1111 / j .1439-0329.2006 .00453 . x$

Lyr H (1958). Die Krankheiten der Douglasie. In: "Die Douglasie und ihr Holz" (Göhre K eds). Akademie Verlag, Berlin, Germany, pp. 369401.

McCutcheon TL, Carroll GC, Schwab S (1993). Genotypic diversity in populations of a fungal endophyte from Douglas fir. Mycologia 85(2): 180-186. - doi: 10.2307/3760454

Misaghi IJ, Dondelinger CR (1990). Endophytic bacteria in symptom-free cotton plants. Phytopathology 80: 808-811. - doi: 10.1094/Phyto-80808

Morgenstern K, Krabel D (2013). Rhabdocline needle cast - Investigations on various Douglasfir tissue types. European Journal of Plant Pathology. [submitted]

Oses R, Valenzuela S, Freer J, Sanfuentes E, Rodriguez J. (2008). Fungal endophytes in xylem of healthy Chilean trees and their possible role in early wood decay. Fungal Diversity 33: 77-86.

Petrini O (1991). Fungal endophytes in tree leaves. In: "Microbial Ecology of Leaves" (Andrews JH, Hirano SS eds). Springer, New York, USA, pp. 179-197.

Petrini O, Sieber TH, Toti 1, Viret O (1992). Ecology, metabolite production, and substrate utilization in endophytic fungi. Natural Toxins 1: 185-196. - doi: 10.1002/nt.2620010306
Saikkonen K, Feath SH, Helander M, Sullivan TJ (1998). Fungal endophytes: a continuum of interactions with host plants. Annual Review of Ecology and Systematics 29: 319-343. - doi: 10.1146/annurev.ecolsys.29.1.319

Saikkonen K, Wa P, Helander M, Faeth SH (2004). Evolution of endophyte-plant symbioses. Trends in Plant Science 9 (6): 275-285. - doi: 10.1016/j.tplants.2004.04.005

Sieber T (2007). Endophytic fungi in forest trees: are they mutualists? Fungal Biology Reviews 21: 75-89. - doi: 10.1016/j.fbr.2007.05.004

Schulz B, Boyle C (2005). The endophytic continuum. Mycological Research 109: 661-686. doi: $10.1017 / \mathrm{S} 095375620500273 \mathrm{X}$

Stone JK (1987). Initiation and development of latent infections by Rhabdocline parkeri on Douglas-fir. Canadian Journal of Botany 65: 2614-2621. - doi: 10.1139/b87-352

Stone JK, Petrini O (1997). Endophytes of forest trees: a model for fungus-plant interactions. In: "The Mycota. V. Plant relationships. Part B" (Carroll GC, Tudzynski P eds). Springer-Verlag, Berlin, Germany, pp. 129-142.

Stone JK, Polishook JD, White JF (2004). Endophytic fungi. In: "Biodiversity of fungi. Inventory and monitoring methods" (Mueller GM, Bills GF, Foster MS eds). Elsevier, Amsterdam, the Netherlands, pp. 241-270.

Stephan BR (1980). Prüfung von DouglasienHerkünften auf Resistenz gegen Rhabdocline pseudotsugae in Infektionsversuchen. European Journal of Forest Pathology 10 (2-3): 152-161. doi: 10.1111/j.1439-0329.1980.tb00021.x

Stephan BR (1981). Douglasienschütte Merkblätter der Forstlichen Versuchs- und Forschungsanstalt Baden Württemberg, Nr. 2. Verlag Paul Parey, Hamburg/Berlin, Germany.

Van Vloten H (1932). Rhabdocline pseudotsugae Sydow, oorzak eener ziwekte van Douglasspar. Proefschrift, Landbouwhoogschool, Wageningen, the Netherlands, pp 168.

Wilson D (1995). Endophyte - the evolution of a term, and clarification of its use and definition. Oikos 73: 274-276. - doi: 10.2307/3545919

Wulf A, Schumacher J (2005). Die Waldzustandssituation 2005 in der Bundesrepublik Deutschland. Forst und Holz 60: 503-505. 